\title{
A Note on Quality of Life of Artisanal Small-Scale Fishermen Along the Pacific Coast of Jalisco, México
}

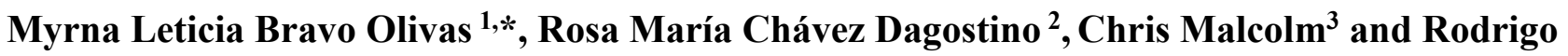 Espinoza $^{4}$}

1 Biosystematics, Ecology and Management of Natural and Agricultural Resources Program (BEMARENA), Biological Sciences Department, Centro Universitario de la Costa, Universidad de Guadalajara. Av. Universidad 203 Puerto Vallarta, Jalisco, México. CP 48280

${ }^{2}$ Biological Sciences Department, Centro Universitario de la Costa, Universidad de Guadalajara. Av. Universidad 203 Puerto Vallarta, Jalisco, México. CP 48280

${ }^{3}$ Department of Geography, Brandon University. Fourth Floor, John R. Brodie Science Centre, 27018th street, Brandon, Manitoba R74 6A9.

${ }^{4}$ Administrative-accounting Studies Department. Centro Universitario de la Costa, Universidad de Guadalajara. Av. Universidad 203 Puerto Vallarta, Jalisco, México. CP 48280

E-Mails: myrnabravo@yahoo.com.mx; rosac@cuc.udg.mx; malcolm@brandonu.ca; rodrigoe@cuc.udg.mx

** Author to whom correspondence should be addressed; Tel.: +52-322-2262200 Ext. 66305.

Received: 30 August 2014 / Accepted: 12 October 2014 / Published: 1 November 2014

\footnotetext{
Abstract: Sustainable fishing includes how fishermen live. We describe the quality of life (QOL) and lived experiences of fishermen along the coast of Jalisco, whose average daily income is slightly above the poverty level. The relationships among income, size of catch and QOL are explored using data collected in 2012 from a sample of 83 fishermen. QOL included indicators like health, income, cost of living, family, friends, holidays, education and future perspective. The QOL index combines importance and achievement ratings scores, the results are indicative of an acceptable QOL for fishermen. The concept of lived experiences is elaborated and interviews conducted with a sample of 13 fishermen. A graphical representation of four dimensions of lived experiences comprising aspects of life relating to Mind, Body, Work and People for each fisherman is derived, where each person was asked on the importance and gaps between aspiration and actual situation about each dimension. We found that the most important dimension in a fisherman's life is People. The gaps identified suggest that those that should be closed were associated to the Mind dimension, followed by Work, Body, and
} 
finally People. Responsibility for closing the gaps were identified, by frequency, as: self, government, self with the help of family members, and God/ faith. An inverse moderately strong relationship between catch, marginalization and QOL score was found, while income and QOL score were directly related. In general, future and past are not better than the present. All these and lived experiences are discussed in the sustainability context.

Keywords: lived experiences, sustainable fishing, gap.

\section{Introduction}

Fishing is an important economic and social activity that humans have practiced from the time of prehistory wherever access to water is available. Every year in the world more than 100 million tons of fish are caught and together with fish products contribute significantly to human well-being by providing a way of life to approximately 200 million people. More than a billion people, especially in poor countries depend on fishing to satisfy their needs for animal proteins. Fishing also promotes human well-being by contributing to cultural needs, for example, for the Amazonian ritual Yakwa ${ }^{1}$ and as a food supply, besides providing other social benefits [13].

This important activity is carried out in Latin America mainly by organized fishermen, in Mexico associated in cooperative ${ }^{2}$ organization, using traditional fishing gear and methods, such as gillnets and hook. They are considered one of the most vulnerable social groups in the country. Although the country has grown richer in general, CONEVAL [7] argues persuasively that poverty ${ }^{3}$ has increased at the same time, and particularly rural poverty. Most coastal fishing communities are situated in rural areas in México and in spite of the fishing potential of the country, this activity does not contribute significantly to the gross national product; however, for a large number of coastal inhabitants, fishing is the only possibility to develop a local economy. If the prevailing conditions in these communities are poverty and negative environmental impacts of fishing, what can be said about their social aspects of sustainability and how can be measured?

Sustainable fishing has mainly been focused on achieving success in conservation challenges by balancing the social and economic needs of human communities with the maintenance of healthy ecosystems [39], but what are the social conditions and measurable indicators required to achieve this balance?

\footnotetext{
${ }^{1}$ Yakwa ritual is the largest indigenous ritual in the Brazilian Amazon. The Enawene Nawe built intricate wooden dams across the river Juruena to catch lots of fish. They encamp in the forest and then sent back to the village by canoe. When men and children come back from the fields of fisheries, food is a ritual exchanged with the spirit world in elaborated ceremonies.

${ }^{2}$ A cooperative organization is a voluntary association of people who seek common benefits and all participate in making decisions. The cooperative movement was strengthened in recent years in Mexico, as a response to the difficulties imposed by neoliberal model.

${ }^{3}$ CONEVAL, a government office reported that $45.5 \%$ of Mexican people were poor in 2012 and defines poverty as when a person have at least one social deprivation (educational backwardness, access to health services, access to social security, quality and living spaces, basic housing services and access to food) and income is insufficient to purchase the goods and services required to meet their dietary needs and food.
} 
Trying to understand a community has been increasingly accompanied by preoccupations related to sustainability, wellbeing and quality of life [21] but efforts to determine social sustainability confront a series of methodological issues such as: whether to follow an objective or subjective assessment, measure at the community or individual scale, and focus on the present or future. The literature relating sustainability, wellbeing and quality of life indicators, have increased significantly recently and most of the studies attempt to quantify and qualify these concepts; however there is not widespread agreement. Even so, the concept of QOL has been used as a multipurpose indicator of development [36] and is closely linked to other indicators such as happiness and contentment.

Some researchers have proposed that objective dimensions provide little or no information about the QOL of individuals [12; 9; 36], so most research has focused most on subjective components of QOL. Although there is a lack of universal agreement about theory or procedure to measure QOL [12; 17], research reveals that health, wellbeing, ratings of quality of QOL, life satisfaction and satisfaction with environmental quality of life are core elements of QOL.

In recent years researchers have combined liveability and comparison theories to explain people's perception about QOL, by accepting that the concept implicates both theories: norms and comparisons [15].

Massam [25] reviewed and expanded the QOL concept with respect to public planning and private living, including how satisfied individuals are with their own lives [24]. It is also accepted that the QOL of an individual is definitely affected by the social and natural environment, so that the forms of measurement are also varied and in many cases quite complex because of the number of factors employed. The World Happiness Report reflects a worldwide concern with respect to happiness and the absence and alleviation of misery as a more significant element of public policy than the measurement of QOL per se without related policy-making implications concerning well-being and sustainability [16]. The report also discusses the ways that happiness can be defined and evaluated in terms that impinge on lived experiences. Another focus of the life quality concept redirects attention to intangible cultural values experienced, which takes into account the personal experiences of life as perceived and evaluated by individuals [3], which improves the understanding about important things for individuals.

We propose here to asses QOL and lived experiences as a way to measure social sustainability aspects of fishing communities, using the objective/subjective, community/individuals and past/present/futures elements. In this note first we comment on the importance of the coastal small scale fisheries to local economies in Mexico, especially along the Jalisco coast. Then we report on a survey of quality of life in selected fishing communities using a methodology developed in Canada at the University of Toronto by Renwick and Brown [31], and then we present an exploration of lived experiences 
developed by Massam et al. [24]. We relate fishing catch to a marginalization index and perception by fishermen of their future lives.

\subsection{Background}

The QOL of fishermen and lived experiences

The characteristics of fishermen differ from region to region and also by the type of fishing they practice. Their problems, expectations and perceptions can be very different ranging from deep sea fishing to those who fish in coastal waters, so generalizations about the QOL of fishermen cannot be easily inferred [28]. One recognized generalization however is that coastal fishermen in Latin America are considered as poor people with low income who live in areas classified as rural as opposed to urban. Income as an indicator of overall QOL is less relevant to life satisfaction perception, than frequently assumed as pointed out Kenny [15]. The question is how important is income for these people and how satisfied are they with their lives related to their personal values and expectations.

Studies of the QOL of fishermen have often focused on risks at work and the effects on families because of the importance of these inherent dangers of fishing. Bering Sea Pollock fishing for example is characterized by high levels of physical risk, uncertainties in wages and schedule and long absences from home. This occupation leads to considerable impacts on the family. Robinson [33] examined the effects of occupation on the QOL and working life through a teamwork perspective. The breakdown in family cooperation reduces the family's ability to respond to its members' needs for love, inclusion and intimacy, and this has important ramifications for the quality of family life. The enhancement of cooperation in the work setting contributes to the creation of important social benefits such as trust, agreement and a sense of inclusion. These social outcomes and improved task performance influence the quality of working life in positive ways.

Ramírez-Acosta [30] determined that in la Ciénega de Mallorquín, Colombia, fishermen had medium to low mental health level highly that was related to the threatened fishery resources and also that the physical risks were not significant to their physical health. Udho [35] studied Ibaka and James Town communities in Nigeria and described the lack of infrastructural amenities such as electricity, medical facilities, potable water, storage facilities and fishing gears. He found insignificant relationship between the socioeconomic characteristics and QOL. He suggested how government and financial institutions could help these communities to improve their income and QOL.

Nowadays global goals of humanity are to eradicate misery and poverty, and increase QOL, strategies to achieve these goals at different scales have been elaborated. As pointed by Massam et al. [24], the analysis of Lived experiences and its interpretation may help the individual to reflect about the important things in their own life, and then make modification to the living patterns in order to balance elements of wellbeing, dignity and contentment that relate to Mind, Work, People and Body 
dimensions of life: all of which can contribute to an individual's efforts to live a good life and so achieve a high QOL. The individual interpretations of patterns among the four dimensions can be used to elaborate public policies to allow and encourage individuals to succeed.

Studies of QOL, for example as developed by Brown, Raphael and Renwick [4] often use questionnaires to ask the opinion of individuals about the relevance or importance of indicators concerning aspects of QOL, and the level of achievement for each indicator and to provide rating scores for importance and achievement. The scores are combined arithmetically to derive an overall cumulative score of QOL. However, these numbers will not reveal behavior patterns or the experiences of an individual's life on matters like satisfaction or distress as manifestation of QOL. This important point has been elaborated by the Nobel prize-winner Kahneman [18]. Instead of just stating numerical levels of QOL, the approach suggested by Massam et al. [24] is to observe the revealed patterns of activities as a surrogate for QOL. He asked individuals to identify their lived experiences over a specific period of time rather than ask them the explicit question namely 'how good is your life for you now?' Kahneman [18] argues convincingly that asking this question explicitly about QOL distorts the reality for the interviewee by forcing them to reflect on a conceptual matter that they normally do not take into account as they go about their daily lives.

Research context: The fishermen along the coastal region of Jalisco, México

The studies related to social aspects of coastal fisheries in the region are scarce but they do provide some insight into the weakness of the fishing sector. Villaseñor-Anguiano and García de Quevedo [37] described the fisheries on the coast of Jalisco and found that there are few registered fishermen and many work without permits; there are a considerable proportion of unrecorded catches and very poor infrastructure. They calculated that almost $40 \%$ of the total fishing catch is not recorded. In the collection centers there is insufficient infrastructure, in addition a lack of basic services like water, ice and fuel. This situation makes it very difficult for the government to plan improvements. The lack of good data and reliable information militates against systematic long-term successful planning in the fishing sector of the economy.

Alcala-Moya [1] noted that in some places like Puerto Vallarta, El Rebalsito, Melaque and Barra de Navidad, fishermen have been displaced from their original settlements to make way for large-scale macro-tourism projects, and the growth of the ports. Some tourist projects along the coast have promoted the "forced sale" of communal land properties since 1970s and this situation continues.

Esquivel-Hernández and Reyes- Plascencia [11] describe the disruption of the fishing organization, noting that many fishermen work without permission in an unregulated fashion, and no catch levels are recorded, likewise they mention the lack of infrastructure. Alcalá-Moya [1] provides a characterization of the fishing zones of the Pacific coast of Mexico. Reports of the case of Puerto Vallarta, since 
becoming an important tourist center indicate that fishermen and their families have been relegated to the outskirts of the city and also fishing has become a secondary activity. In recent years men divide their working time between fishing and working in hotels and restaurants.

Despite the economic and social importance of coastal fishermen, research on the coast of Jalisco is mainly based on the knowledge of commercially important marine resources existing in the area. RíosJara et al. [32], Lucano-Ramírez et al. [20], Rojo-Vázquez et al. [34], Moncayo-Estrada et al. [26], García-Rivera [14] and Espino-Barr et al. [10] elaborate on the stresses on fishing activities and note that there are many species of fish caught as well as species of crustaceans, mollusks and echinoderms. While Pérez-Peña et al. [27] offer diagnostic work on the fishing industry and marketing challenges in Jalisco they offer no comments on matters of quality of life of fishermen and their families.

Moreover Chávez-Dagostino et al. [5] analyzed the impact of tourism in five fishing communities in the Banderas Bay at the north of the Jalisco coast and determined the ecological footprint and quality of life of fishermen. Here they identified some perceptions of good quality of life as defined by fishermen. Also they report on high future expectations and the low incomes in fishing communities; conditions that make the achievement of a sustainable economy unviable. This is partly ameliorated because fishing is not the only activity fishermen undertake, most of them have temporal employment in the tourist sector.

The studied area in this work is located on the Pacific coast of México in Jalisco state; this is shown on Fig. 1. The coast of Jalisco is delimited by Nayarit state and Ameca river to the north and by Colima state and the Cihuatlán river to the south. The region includes the municipalities of Puerto Vallarta, Cabo Corrientes, Tomatlán, La Huerta and Cihuatlán. 
Fig. 1. The study area and sampling sites along the coast of Jalisco: Localities-1. Puerto Vallarta (In Puerto Vallarta municipality), 2. Chimo (Cabo Corrientes municipality), 3. Cruz de Loreto (Tomatlán municipality), 4. Punta Pérula (La Huerta municipality), 5. Barra de Navidad (Cihuatlán municipality).

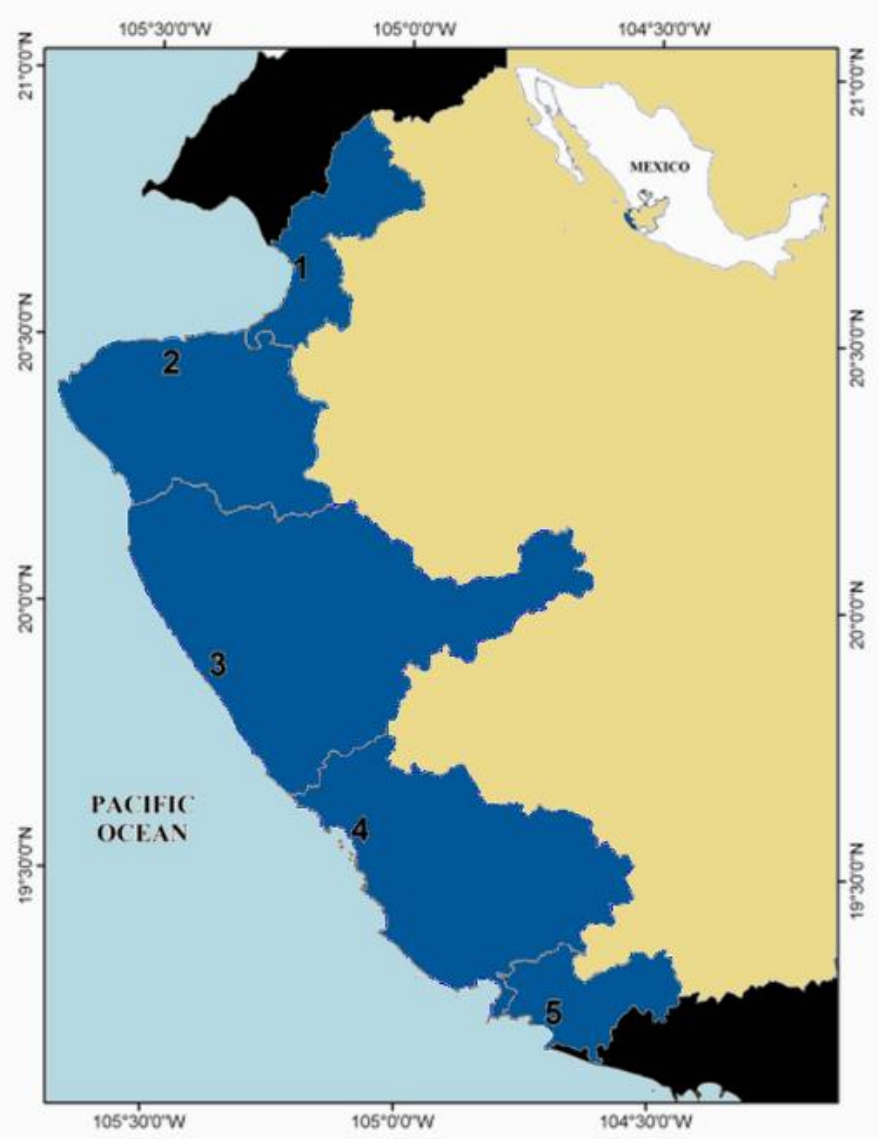

The fishing gear used by fishermen off the coast of Jalisco include gillnets, hand line, cast nets, long lines, seine, crab ring and diving equipment in few cases (Bravo-Olivas 2014). Fishing cooperative organizations in the region are allowed to fish for octopus, lobster, flake, crab, shrimp, rock oyster, gorro (Chinese hat gastropod) and river shrimp. The catch is distributed in the villages for selfconsumption as well as in the cities of Puerto Vallarta, Guadalajara and the states of Colima, Guerrero and Sonora. The recorded catches include 75 species: $94 \%$ of registered species are fish, 4\% crustaceans and $2 \%$ mollusks. The largest catches correspond to fishes and octopus which together represent $80 \%$ of the total catch.

\section{Results and Discussion}

\subsection{General characteristics of fishermen}

All individuals included were males, as women collaborate in fishing near-shore but are not registered as member in a cooperative organization. Most of males indicated that their sole occupation was fishing (43\%), while others combine this activity with another primary sector activity such as agriculture (37\%). The ages of the fishermen varied between 16 and 69 years, most of them were in the 
range of 35 to 50 years (Fig. 2). Less than a half had completed elementary school. Most of them were born in the same community were they worked and they lived in their own house.

Fig. 2. Age range of respondent fishermen

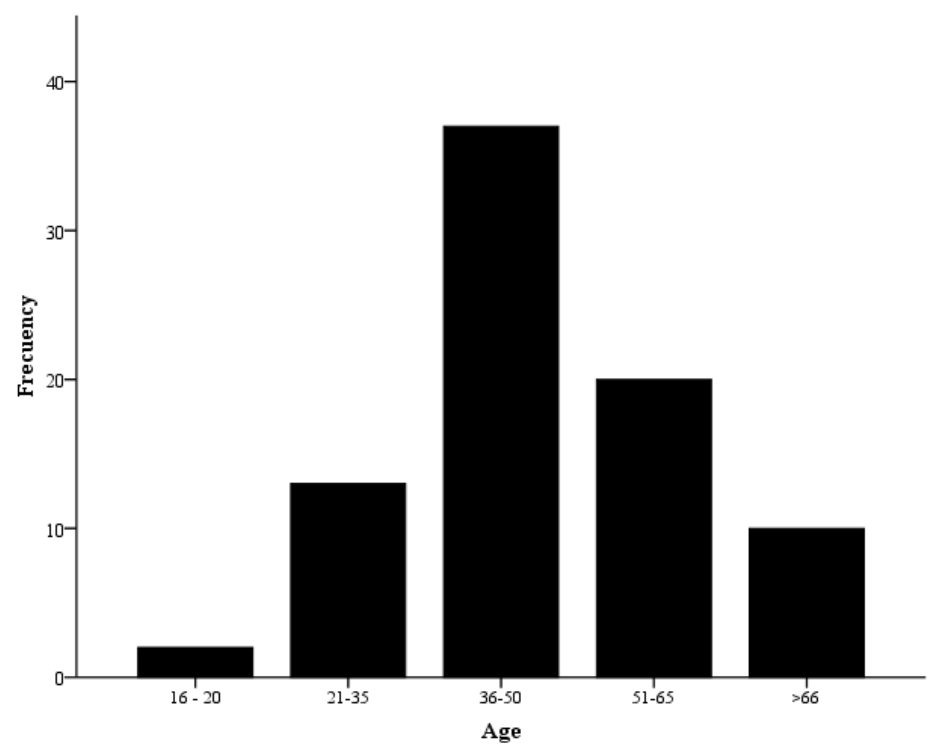

The monthly income ranged from US\$ 64 to more than US\$ 485, but most earned between US\$ 242 and US\$ 485. A very low percentage of fishermen had a monthly income larger than US\$ 500 (Fig. 3). Almost $65 \%$ of the interviewed fishermen claimed to have social security, but not as part of the cooperative organization benefits: as members they had to pay an annual fee for having a popular health insurance plan at a low cost (less than US\$ 84): the poorest families are exempt from payment.

Fig. 3. Average monthly income of fishermen on the coast of Jalisco

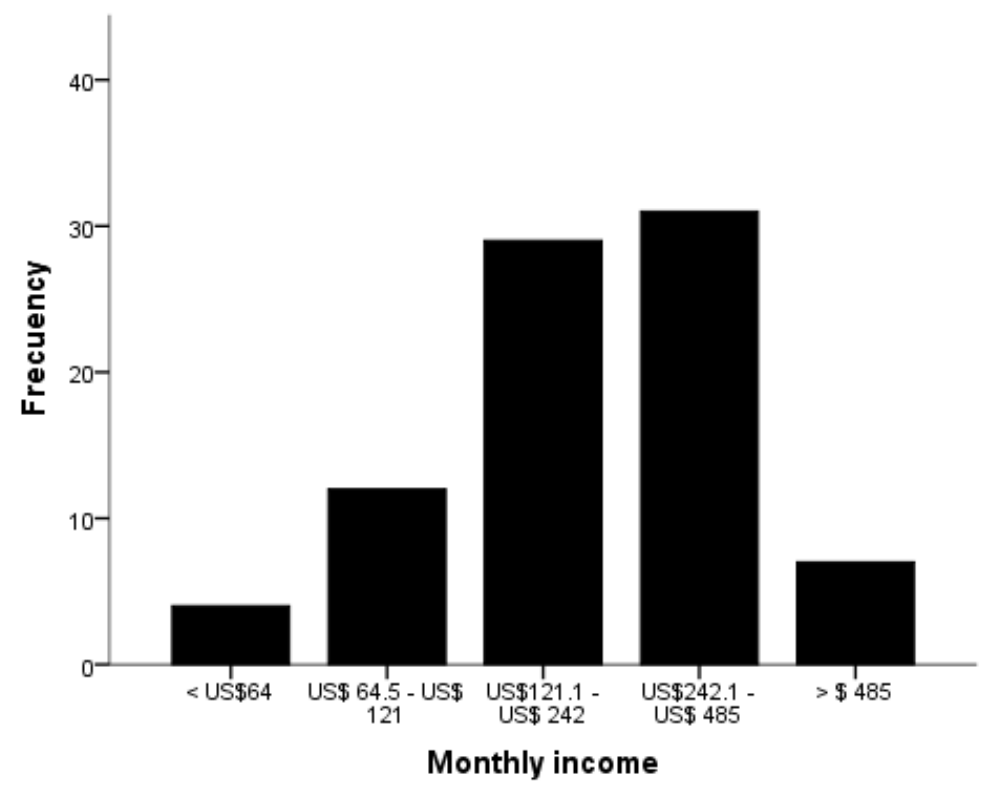


The fishermen in the cooperative society at Puerto Vallarta were between 21 and 65 years old, all were born in the community and $75 \%$ combines their economic activity of fishing with another activity in the secondary sector. In this community, fishermen have achieved a high level of education $50 \%$ at the end of high school. The monthly incomes of fishermen in this community were between US\$ 152 and US\$ 760.

In the community of Chimo, respondents were between 21 and 70 years old (Fig. 5), about 90\% were born in the same community they lived and worked. Although some have sole fishing activity, as shown on figure 6 others $(64 \%)$ are engaged in fishing and agriculture. Most fishermen had an unfinished basic education level. Their monthly income is between US\$ 75 and US\$ 455 (Fig. 7).

The respondents in the 'SCPP fishermen of La Cruz de Loreto' are between 21 and 70 years old (Fig. 5), about $76 \%$ were born in the community but are also some who came from other states of Mexico to live in La Cruz de Loreto. In this community fishermen practice more diversified labor, 45\% are dedicated solely to fishing, while $31 \%$ practice fishing and agriculture, and other secondary and tertiary sector as shown on Fig. 6, although in all cases their main activity is fishing. About $50 \%$ of fishermen have only primary education that is unfinished. The monthly income of fishermen in this community is between US\$ 60 and US\$ 606 (Fig. 7).

In Punta Pérula the age of fishermen age ranges between 16 and 65 years (Fig. 5), and in this community we find the youngest fishermen. Their birthplace is the same community (72\%). Most have the sole occupation of fishing (71\%) and the rest combine fishing with other activities in the services sector such as tourism (Fig. 6). As to the level of education, about $50 \%$ of respondents have unfinished primary studies. Approximately $40 \%$ have no social security services. The monthly income of fishermen in this community is between US\$ 75 and US\$ 530 (Fig. 7).

Barra de Navidad comprise older fishermen between 21 and 70 years of age (Fig. 4), who were born in the community (58\%). Al most $90 \%$ of respondents indicate their sole occupation is fishing and the rest combine this activity with another activity in the tertiary sector (Fig. 5). Most have basic primary studies (59\%). All live in their own home. The monthly income of fishermen in this community is between US\$ 75 and US\$ 758 (Fig. 6).

The higher incomes are from fishermen who perform some administrative position in the fishing cooperatives. 
Fig. 4. Age of fishermen in each fishing organization

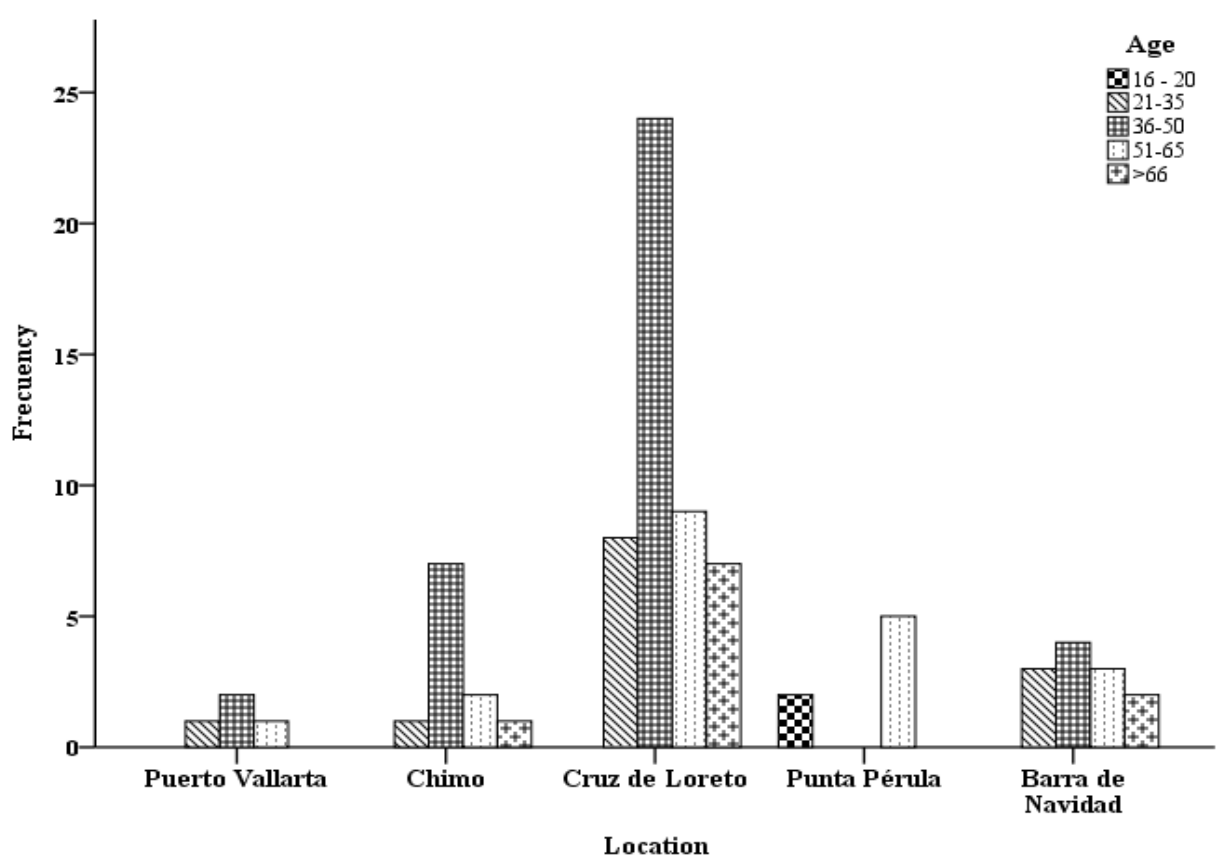

Fig. 5. Occupation of fishermen in each fishing organization

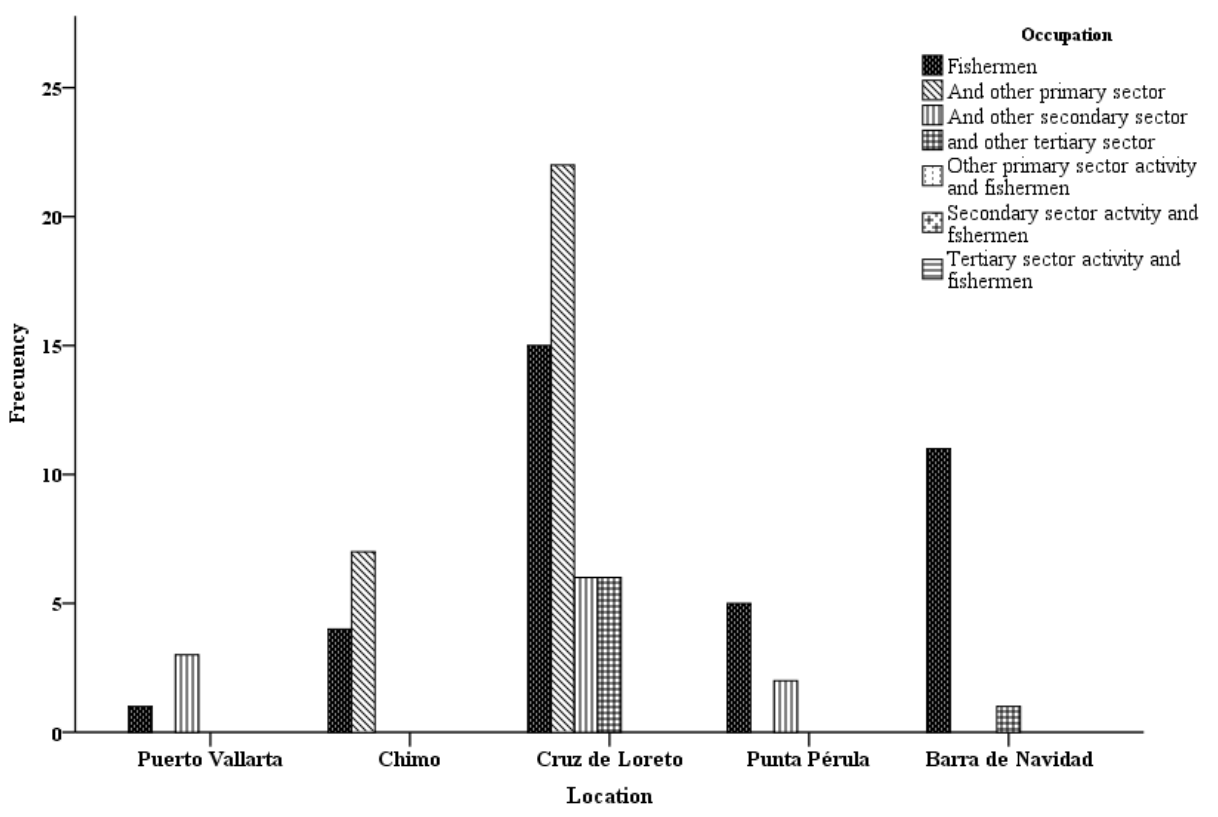


Fig. 6. Average monthly income of fishermen in each cooperative organization

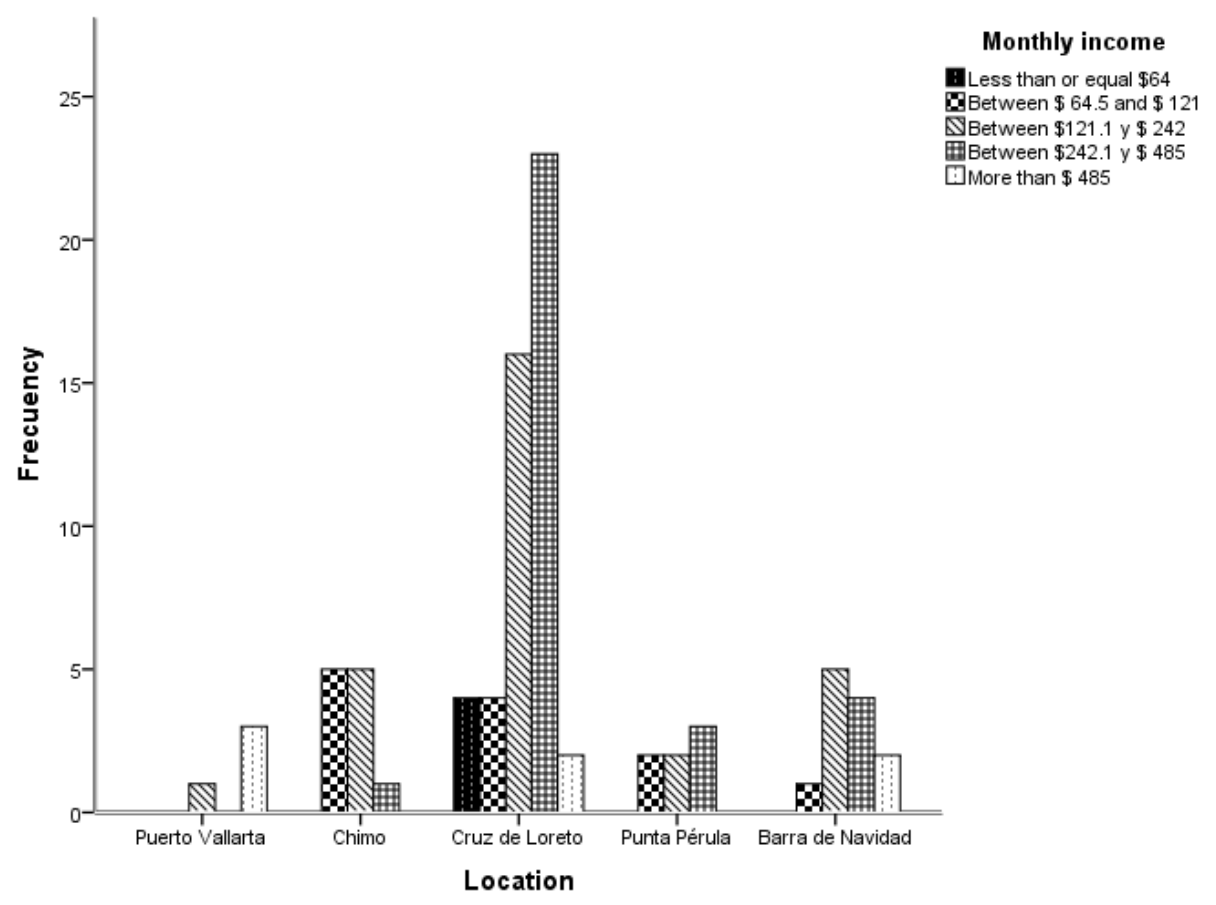

\subsection{QOL analysis}

An overall score of +4.3 was obtained for the five fishing cooperatives. The indicator that provides the highest score is the family $(+10)$; which was the most important and most satisfactory in all areas surveyed. Other issues that respondents consider important and which were satisfied is health with scores between +5 and +10 between cooperatives and general with a score of +7 . By contrast, the indicator with the lowest score was the holidays $(+1)$, indicating that this aspect is not relevant to them (Fig. 7).

The highest QOL score obtained by a cooperative was that of the town of Puerto Vallarta (+7.1), while the lowest score obtained were found in Punta Pérula and Cruz de Loreto ( +3.6 for both). All cooperatives had scores greater than +1.5 , indicating that fishermen perceive their quality of life very acceptable (Cruz de Loreto and Punta Pérula), and excellent (Puerto Vallarta, Chimo and Barra de Navidad) (Fig. 8).

We tested the normality of data using the Kolmogorov-Smirnov test and then decided to apply the Kruskal-Wallis test $(\alpha=0.05)$, since the data did not follow a normal distribution $(\mathrm{P}<0.05)$. The results of the Kruskal-Wallis test showed no significant differences between the values of QOL of fishermen in the five localities (Kruskal-Wallis: $\mathrm{H}(4,83)=8.80, \mathrm{P}=0.066$ ). 
Fig. 7. Average and standard deviation of the quality of life score and indicators for fishermen along Jalisco coast.

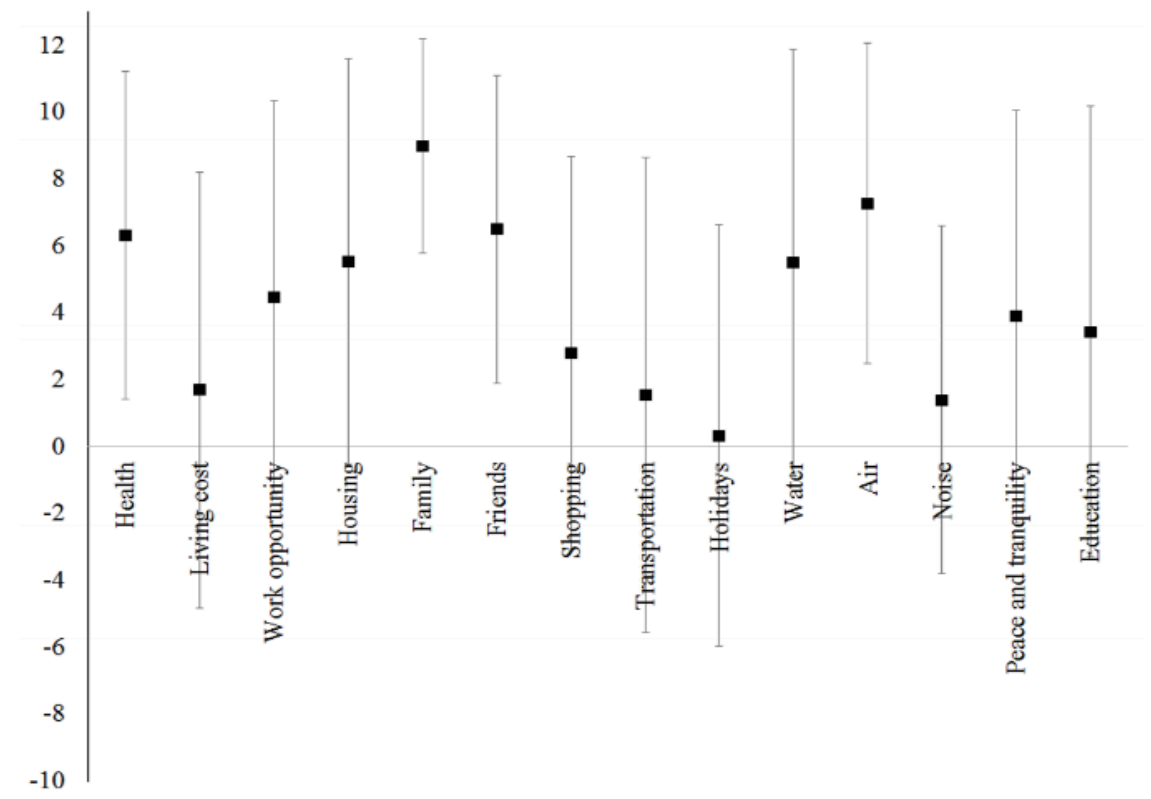

Fig. 8. Average QOL score of fishermen by fishing organization

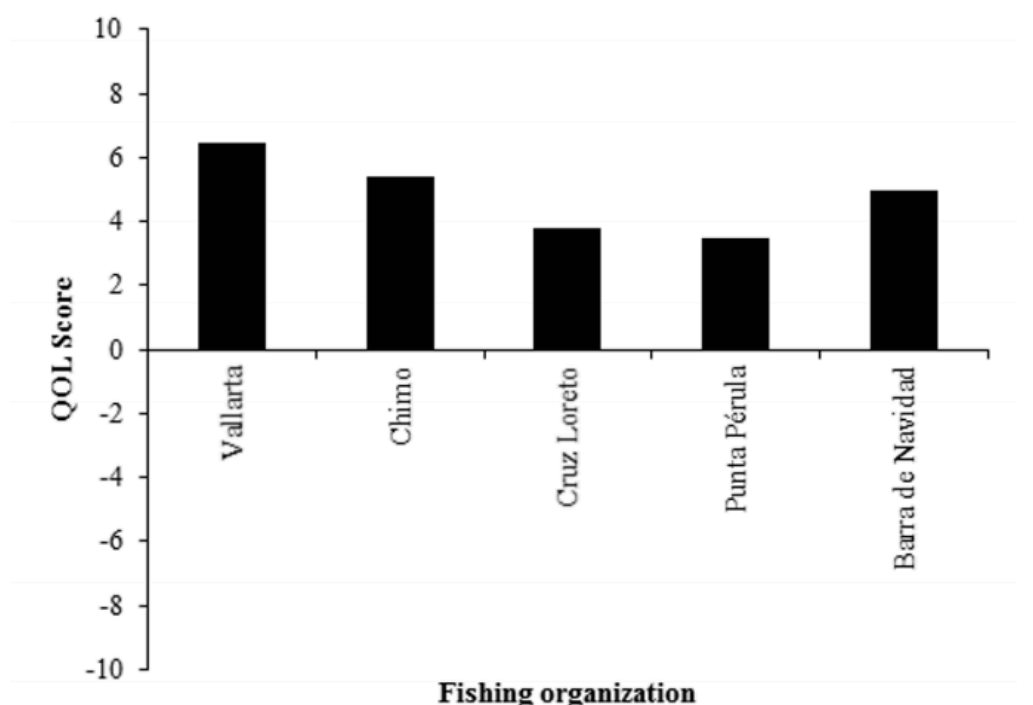

The average QOL numbers for each cooperative in the five localities are shown diagrammatically on Figure 9 using the total catch in tons, and the correlation coefficient was calculated. Both were negatively correlated with a high value $(r=-0.87)$. 
Fig. 9. Total catch and average QOL in each cooperative organization

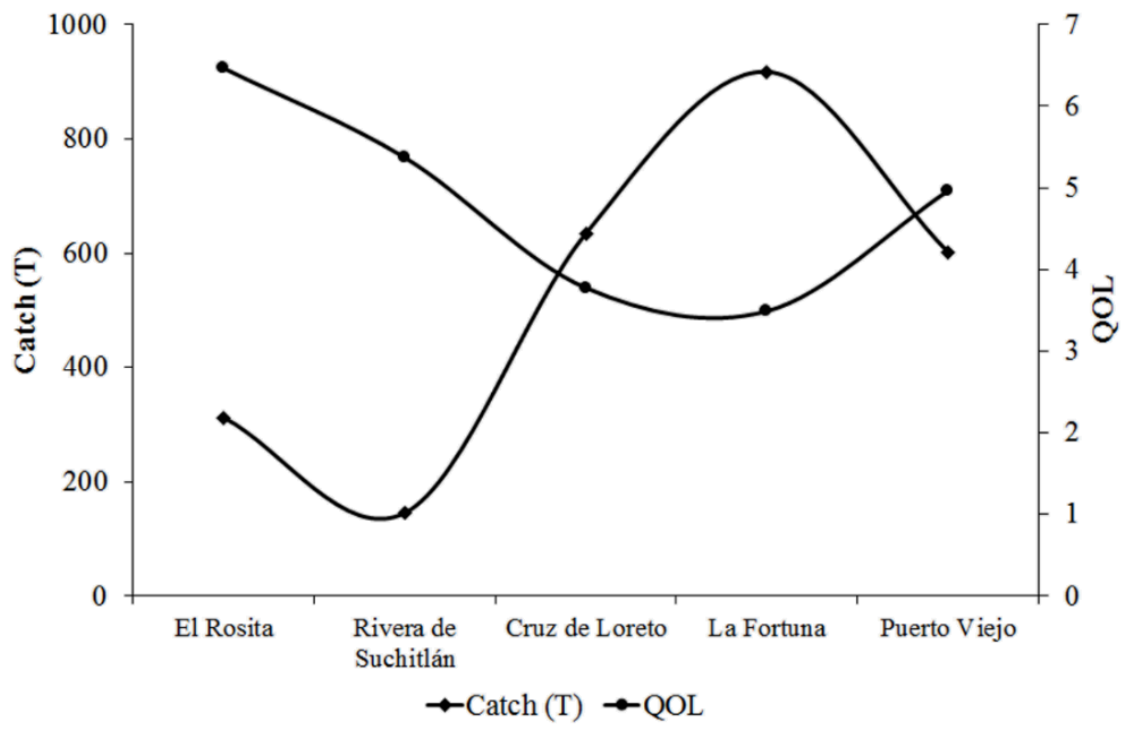

The future is perceived in most cases worse than past and present except for Puerto Vallarta (Fig.10). The main reason expressed by fishermen was the downward trend in the catch in the last 10 years.

Fig. 10. Past, present and future QOL perception in each fishing community

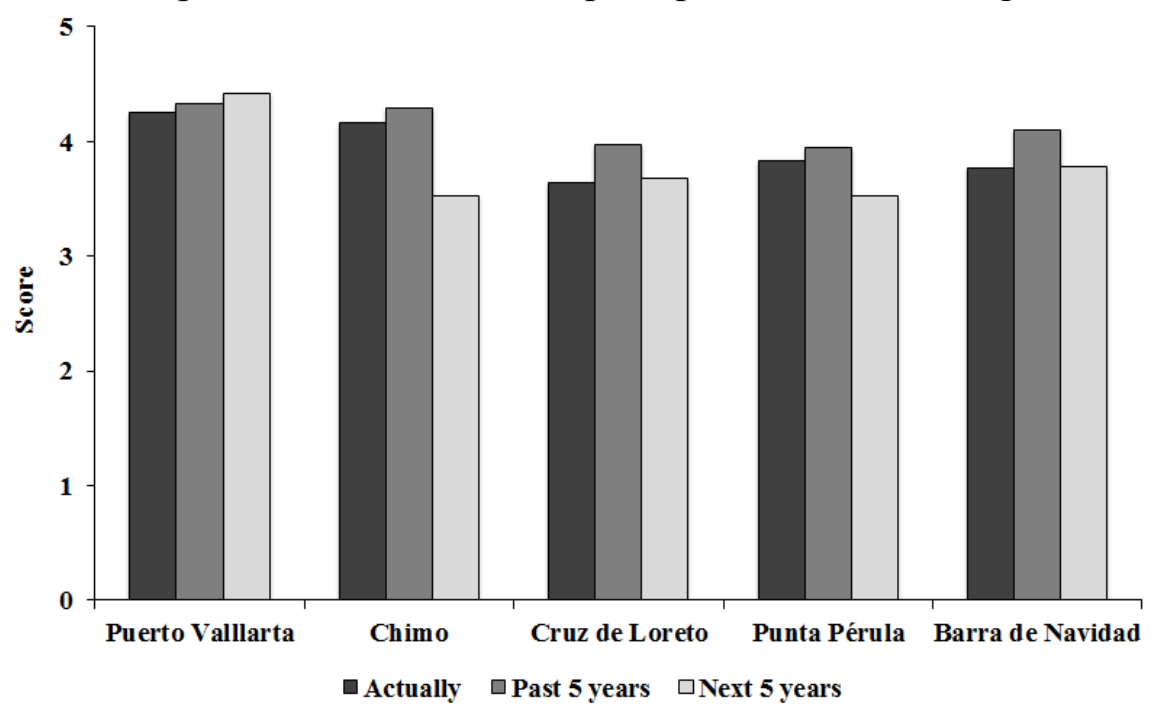

Perceived average QOL by fishermen and monthly average income in each cooperative organization showed a positive and moderately strong relationship $(\mathrm{r}=0.60)$. Chimo cooperative maintains its good perception about their QOL despite their low income (Fig.11). 
Fig. 11. Monthly income and QOL by cooperative society.

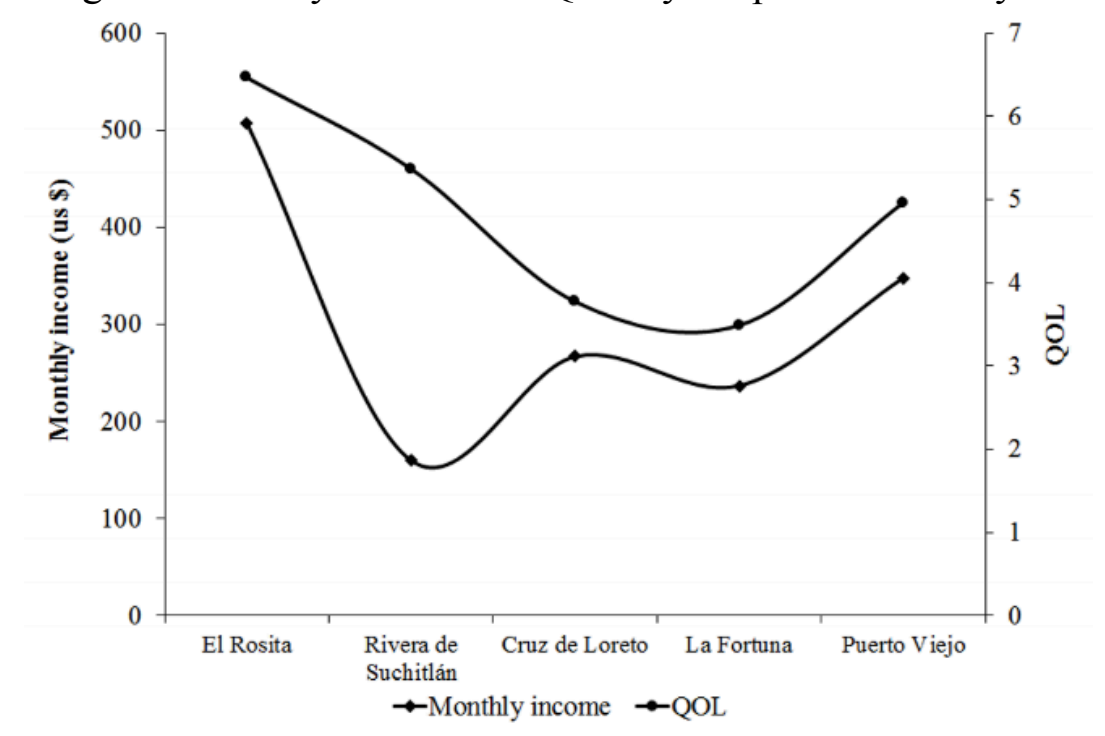

QOL averages for each cooperative organization were related to marginalization index calculated by CONEVAL (2010): Puerto Vallarta 3.93 (very low), Chimo 7.65 (medium); Cruz de Loreto 6.63 (medium), Punta Pérula (7.23) and Barra de Navidad 5.34 (low) using correlation coefficient. This resulted in $r=-0.67$ and shows a negatively moderately strong relationship between marginalization and QOL.

The five case studies of lived experiences in cooperative societies at La Cruz de Loreto (CL) in the municipality of Tomatlán; Punta Pérula (PP) at municipality of La Huerta; Barra de Navidad (BN) at municipality of Cihuatlán and La Rosita (R) at Puerto Vallarta, showed varied patterns related to Mind, Body, Work and People dimensions (Fig. 12-16) (Tables 1-5).

Fig. 12. Fishermen's ideal (broken line) and actual patterns of lived experiences in the cooperative society La Cruz de Loreto (CL1-CL4). M=Mind, P=People, B=Body, W= Work.

CL1
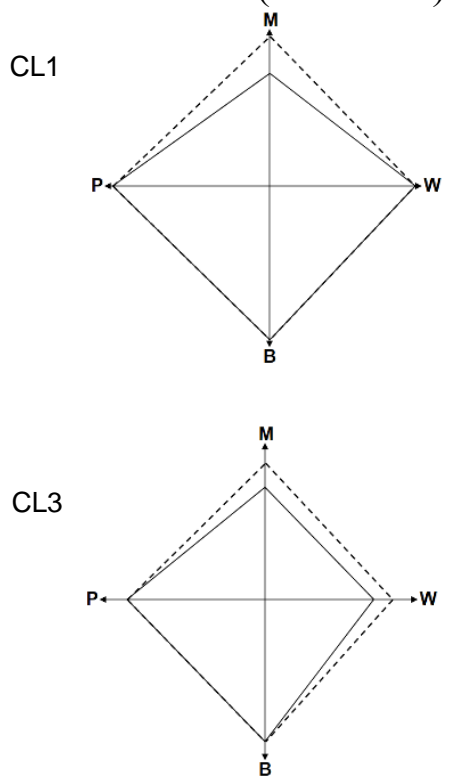
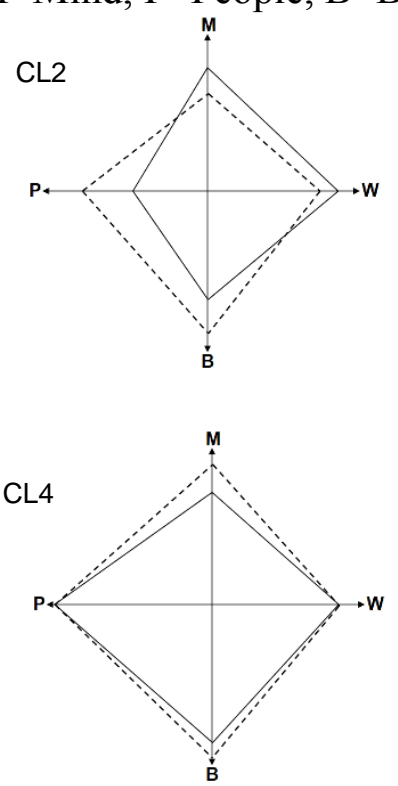
Table 1. Data summary sheet interpretation from La Cruz de Loreto (CL1-CL4)

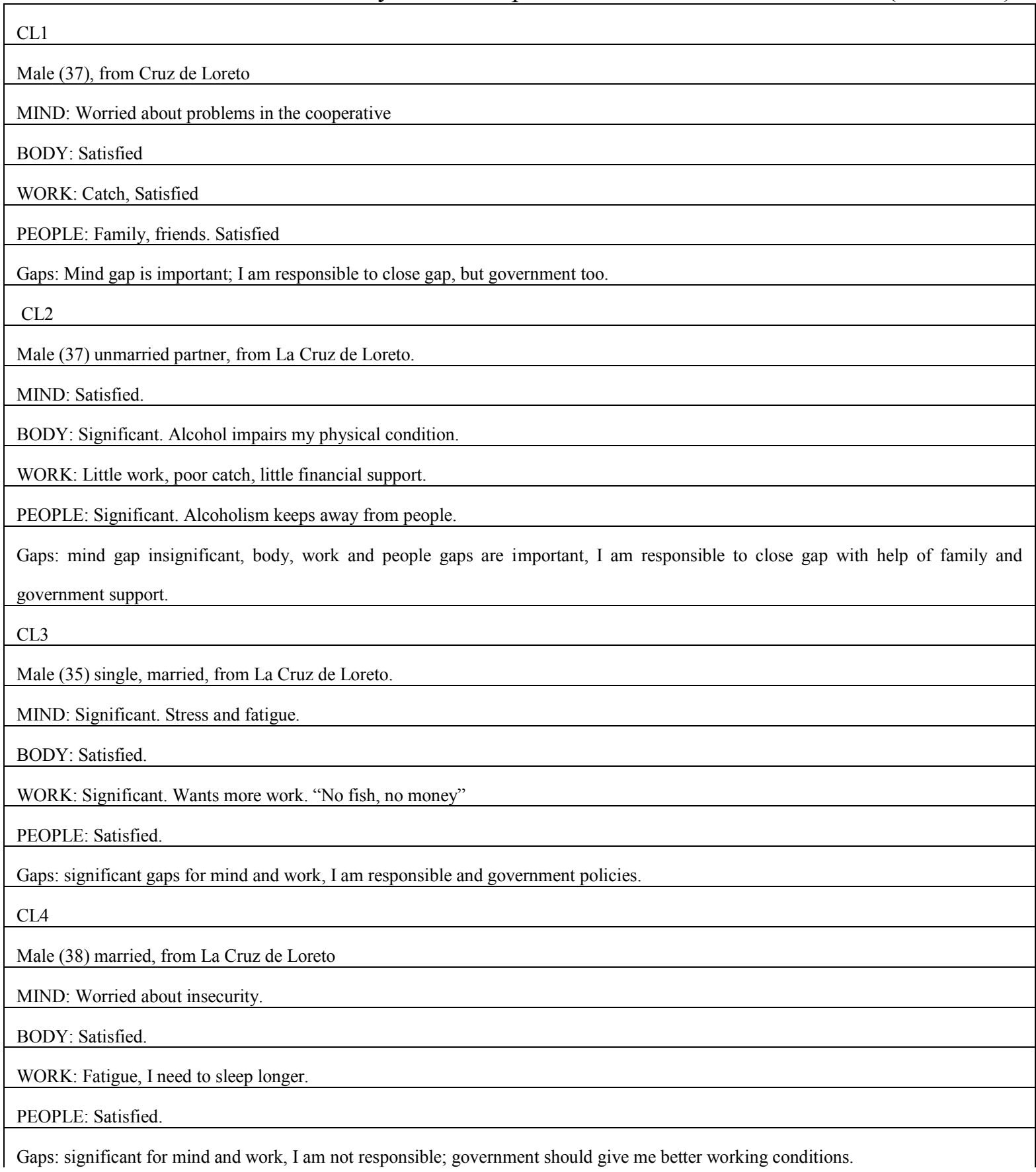

Fig. 13. Fishermen's ideal (broken line) and actual patterns of lived experiences in the cooperative society al Barra de Navidad (BN1-BN3). M=Mind, P=People, B=Body, W= Work
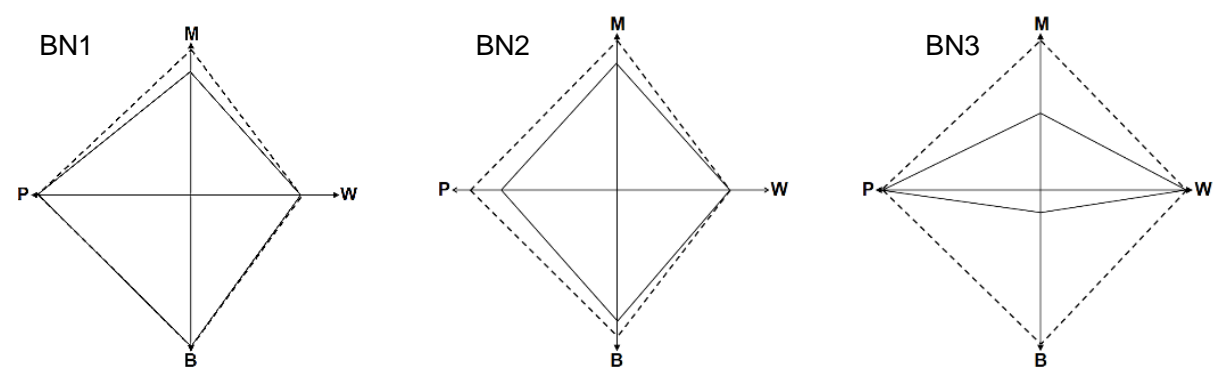
Table 2. Data summary interpretation sheet from Barra de Navidad (BN1- BN3)

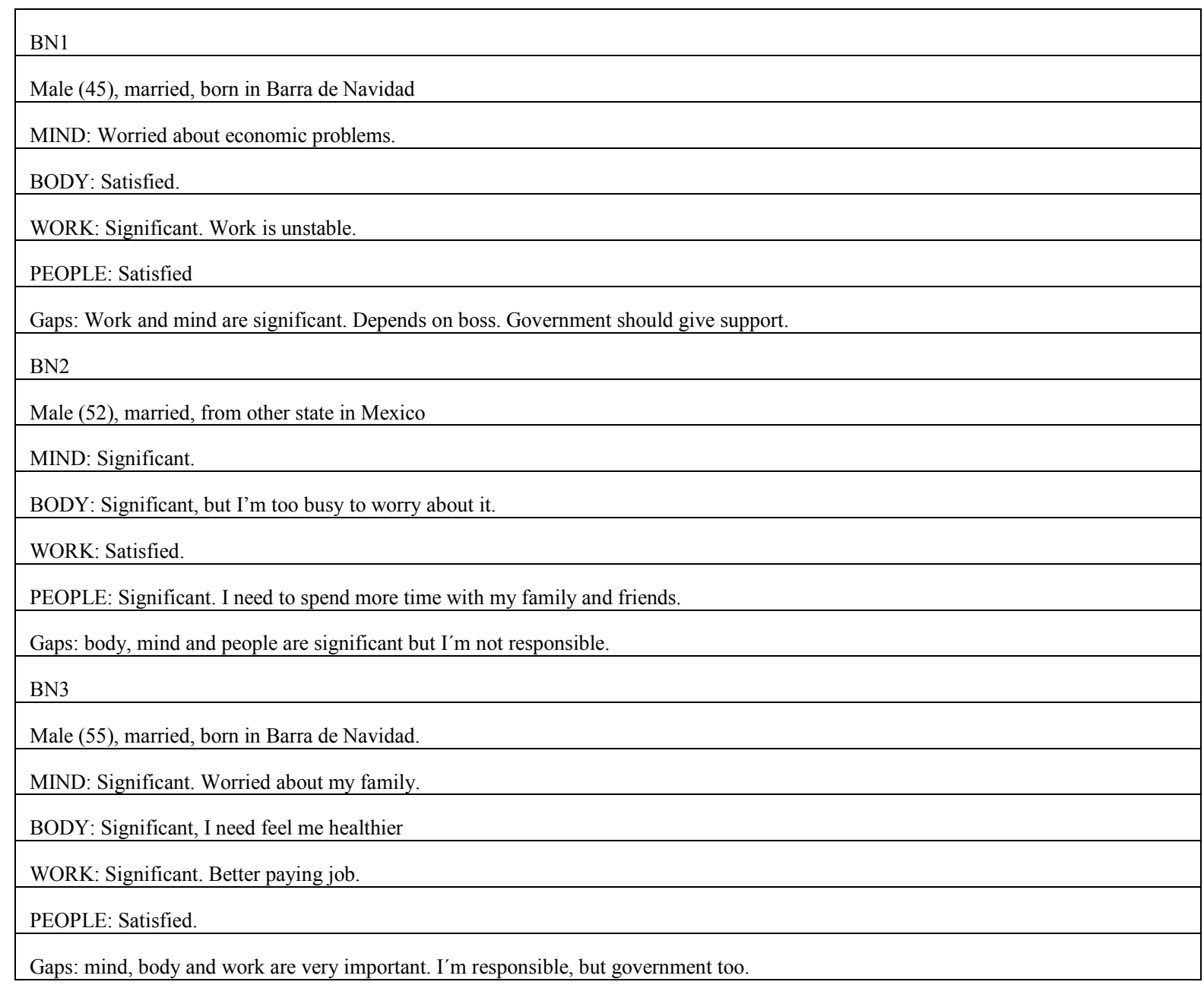

Fig. 14. Fishermen's ideal (broken line) and actual patterns of lived experiences in the cooperative society at Chimo (CH1-CH2). $\mathrm{M}=$ Mind, $\mathrm{P}=$ People, $\mathrm{B}=\mathrm{Body}, \mathrm{W}=$ Work.
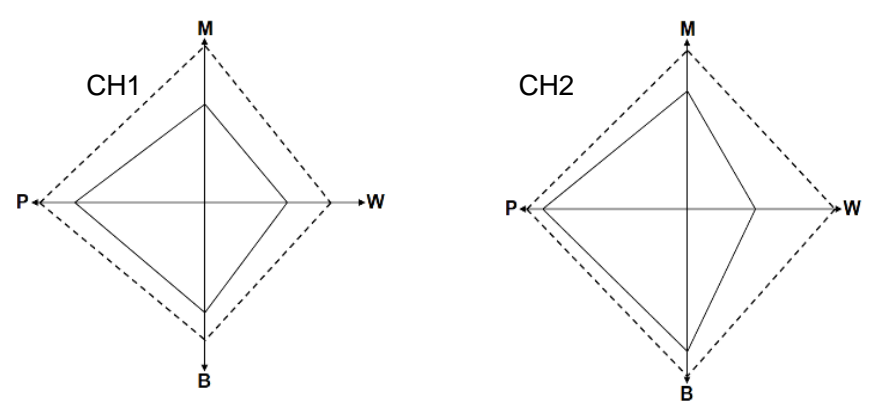
Table 3. Data summary interpretation sheet from Chimo (CH1 - $\mathrm{CH} 2)$

\begin{tabular}{|l|}
\hline CH1 \\
\hline Male (41), married, born in Chimo \\
\hline MIND: significant, worried about economic problems, stressed. \\
\hline BODY: food, health, exercise \\
\hline WORK: Significant. Work is unstable, climate, boat, permission \\
\hline PEOPLE: Family, friends. Satisfied \\
\hline Gaps: Work and mind are significant. Depends on climate and government. \\
\hline CH2 \\
\hline Male (44), married, born in Chimo \\
\hline MIND: Significant. Employment, study. \\
\hline BODY: Significant, but I am too busy to worry about it. \\
\hline WORK: Satisfied. \\
\hline PEOPLE: Significant. I need to spend more time with my family and friends. \\
\hline Gaps: body, mind and people are significant but I'm not the only responsible. \\
\hline
\end{tabular}

Fig. 15. Fishermen's' ideal (broken line) and actual patterns of lived experiences at Punta Pérula cooperative society $(\mathrm{R} 1)$. $\mathrm{M}=\mathrm{Mind}, \mathrm{P}=\mathrm{People}, \mathrm{B}=\mathrm{Body}, \mathrm{W}=$ Work.
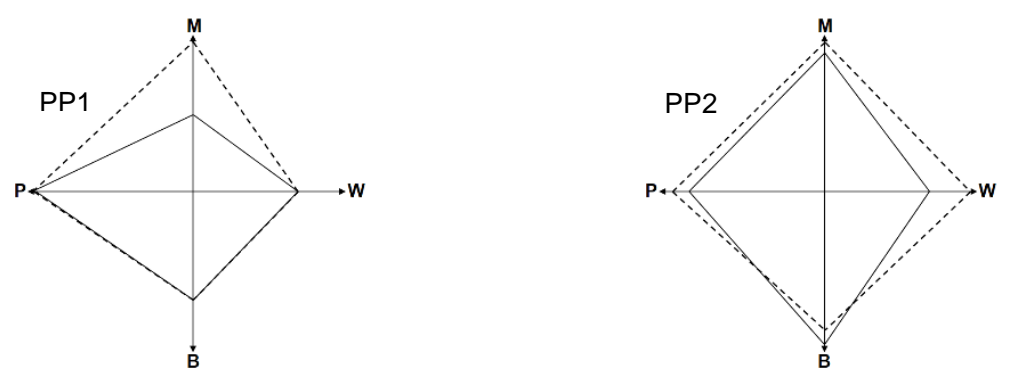

Table 4. Data summary interpretation sheet from Punta Pérula cooperative society

\begin{tabular}{|l|}
\hline P1 \\
\hline Male (26), unmarried partners, 10 years in Punta Pérula. \\
\hline MIND: Worried about financial problems. \\
\hline BODY: Satisfied. \\
\hline WORK: A little more work. \\
\hline PEOPLE: Satisfied. \\
\hline Gaps: Mind and work are significant, boss and government can offer better job opportunities. Time working depends on the sea \\
conditions. \\
\hline PP2 \\
\hline Male (30) unmarried partners, 15 years in Punta Pérula. \\
\hline MIND: Satisfied. I have future plans. \\
\hline BODY: Satisfied despite having muscle diseases. \\
\hline WORK: Significant. Fishing work is unstable \\
\hline PEOPLE: Satisfied, but need socialize a little more. \\
\hline Gaps: work and people gaps are important; I am responsible to close gap with help of God and government support. \\
\hline
\end{tabular}


Fig. 16. Fishermen's ideal (broken line) and actual patterns of lived experiences at La Rosita cooperative society in Puerto Vallarta (R1). M=Mind, $\mathrm{P}=$ People, B=Body, W= Work.

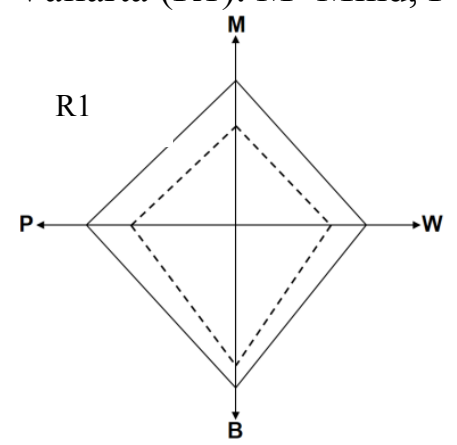

Table 5. Data summary interpretation sheet from La Rosita cooperative society (R1).

\begin{tabular}{|l|}
\hline R1 \\
\hline Male (48), married, born in Puerto Vallarta \\
\hline MIND: Happy, harmony feeling. Very important. Satisfied \\
\hline BODY: Significant, illness, physical culture, health. \\
\hline WORK: Important and satisfied. Lot of work, poor catch and poor income \\
\hline PEOPLE: Very important and satisfied. Family, friends and work companions \\
\hline Gaps: Body is significant and I am the only responsible person to deal with this \\
\hline
\end{tabular}

Some general observations can be offered from these results: the details are contained on each figure and the summary charts. Most of fishermen (11/12) consider the most important dimension People where is included the family, but $8 / 12$ perceive that the four dimensions should be balanced in the ideal scenario of good life. More than a half considered Work the next important dimension and the last important in 10/12 cases was Body.

Most of fishermen showed differences between real and ideal when drawing and Mind in all cases. The significant gaps that should be closed were first Mind, then Work and Body and least important is People.

With respect to the responsibility for closing significant gaps, respondents considered four options which are ordered by frequency as 1 st: self, $2^{\text {nd }}$ government, $3^{\text {rd }}$ self with the family help and God.

Fishermen are male adult individuals who have a low level of education and economical responsibilities with family. Females participate in some fishing like the gastropod known as "gorro" but are not associated to a cooperative organization. The data indicate that fishermen have deep emotional attachment to the communities where they were born and operate in fishing areas nearby their place of residence which is the same in most cases. Typically they feel their roots are in the community and they belong there. This suggests that individuals who engage in fishing do so by choice and not by intellectual or other limitations. 
There is a low recruitment of young people to participate in fishing activities along the coast. This observation could be interpreted as a lack of interest in the activity or the perception of fishing as an unattractive way of living. Although most are dedicated only to fishing, the second most important activity is agriculture. The average monthly income is US \$227.50, the poverty line is defined as US\$ 60.00 per month. Higher incomes are earned by fishermen in charge of the cooperative organization administrative activities, or who are at the same time buyers of fish products. The individual annual income of most of the fishermen does not exceed US $\$ 3,790.00$ for 350 days worked a year. Although most of cooperatives organizations studied are in rural localities, their income is above the poverty line; however, Kenny [19] states that income is not an important related QOL indicator. The cooperative work in these fishing organizations creates important social benefits which affect positively perception of QOL and satisfaction as Robinson [33] established.

Some authors have argued that the nature of fishing attracts active, adventurous and courageous individuals; hence, the risky components of the activity have a positive influence on the perception of life and levels of happiness, so there is more to fishing than money [29].

The factor of major importance in the life of all fishermen is the family. Activities and aspects of life they do not consider important are vacations, cost of living and transportation.

In general, fishermen in Jalisco perceive their quality of life as Very Good and Excellent. The family is the most important aspect that contributes to QOL, while the noise aspect of place or activity is of no importance to them. Fishermen in Puerto Vallarta have the highest perception of their quality of life, while the lowest is perceived by fishermen and Punta Cruz de Loreto Pérula, which however is still perceived as Very Good. There is an inverse moderately strong relationship between the catch/marginalization index and the QOL score, while the relationship between income and QOL is directly related.

None of the respondents mentioned the risk of the activity as important, or the lack of services, however, poor catches stressed fishermen, which is similar to the results found by Ramirez-Acosta [30] and Udho [35]. Fishermen described by Chávez-Dagostino et al. [5] had low income but high future expectations, explained by their hopes for benefits to come from tourism. In this study this perception is a main difference between Banderas Bay fishermen along the north of Jalisco coast, where there is developed tourism activity and those where there is little or no tourism, who report just one type of income, fishing, consequently a lower perception of the future.

Regarding the quality of life perspective, most fishermen think that the future will not be better, except for Puerto Vallarta fishermen, who believe that QOL is improving over time.

Overall it is perhaps surprising to find that the QOL as perceived by fishermen is not directly related to their income. We have used two types of study in this project, namely an objective numerical approach that allows specific QOL scores to be derived and interpreted. We also apply and test an approach of 
asking fishermen about their lived experiences. We believe that the combined approaches have merit as demonstrated by this small scale study, and we suggest that in future research some large scale studies be undertaken over a long period of time to examine trends in perceived QOL of individuals especially as public policies are implement to aid fishing as a sector in the economy, or alternatively to offer individuals in communities alternate economic opportunities.

\section{Methods}

\subsection{The QOL of fishermen}

The study includes registered fishermen in five cooperatives (fishing organization) on the coast of Jalisco. For the life satisfaction perception survey, 83 questionnaires were applied in five localities on the coast of Jalisco. The survey included a set of 14 indicators previously developed and tested in Puerto Vallarta by Massam and Everitt [22]. The first set of questions asked for basic information about each respondent was: gender, age, occupation, birthplace, schooling, marital status, children, and ownership of house, social security and monthly income. Living on less than US\$2.00 a day was considered as the poverty threshold according to the Poverty Index [38].

Questions were designed to provide the raw data about the indicators that are used to calculate QOL scores. The indicators used are health, living cost, opportunity of work, housing, family, friends, shopping, transportation, holidays, water, air, noise, peace and tranquility and education. The cooperatives varied in the number of current partners: $70 \%$ of them in each one were interviewed. Each individual interviewed was asked to score importance and achievement levels following the methodology of Renwick and Brown [31] and Massam [23]. The scores ranged from 1 to 5, where five indicated a very high importance and satisfaction, and 1 indicated a very low level of importance and satisfaction. The value of 3 was interpreted as neutral. The importance and satisfaction (achievement) average ratings for each individual and all the cooperatives used to calculate QOL scores following the procedure of Brown et al. [4] (Table 1). Guidelines for interpreting the QOL scores are shown on Table 2.

The survey included an analysis of fishermen's perspectives, indicating the levels of personal satisfaction; time devoted to recreation and leisure; time spent with his family; time spent on working activities; time spent with friends and the perceived current health status, as well as during the previous five years and the level envisaged in the next five years. The ratings were the same used in the analysis for QOL (1 to 5).

The results were compared to the localities marginalization index, an analytical parameter prepared by the Mexican National Population Commission [6] for understanding when a sector of society is in a situation where opportunities for development and the abilities to achieve it are not present. 
Correlation coefficient was calculated to evaluate the strength between variables: income and QOL; catch and QOL and marginalization index and QOL.

The general data were analyzed using the Statistical Package for Social Science Software Package (Version 17) and Sigmastat (Version 3.5).

Table 6. QOL scores using importance and achievement (satisfaction) ratings. From Brown et al. [4].

\begin{tabular}{|c|c|c|}
\hline If Importance $=$ & And Satisfaction $=$ & QOL Score \\
\hline \multirow{5}{*}{5} & 5 & +10 \\
\hline & 4 & +5 \\
\hline & 3 & 0 \\
\hline & 2 & -5 \\
\hline & 1 & -10 \\
\hline \multirow{5}{*}{4} & 5 & +8 \\
\hline & 4 & +4 \\
\hline & 3 & 0 \\
\hline & 2 & -4 \\
\hline & 1 & -8 \\
\hline \multirow{5}{*}{3} & 5 & +6 \\
\hline & 4 & +3 \\
\hline & 3 & 0 \\
\hline & 2 & -3 \\
\hline & 1 & -6 \\
\hline \multirow{5}{*}{2} & 5 & +4 \\
\hline & 4 & +2 \\
\hline & 3 & 0 \\
\hline & 2 & -2 \\
\hline & 1 & -4 \\
\hline \multirow{5}{*}{1} & 5 & +2 \\
\hline & 4 & +1 \\
\hline & 3 & 0 \\
\hline & 2 & -1 \\
\hline & 1 & -2 \\
\hline
\end{tabular}

Table 7. Interpreting QOL scores. From Brown et al. [4].

\begin{tabular}{ll}
\hline QOL score & Situation \\
\hline Less than -4.5 & Very problematic \\
-1.5 to -4.5 & Problematic \\
-1.5 to +1.5 & Adequate \\
+1.5 to +4.5 & Very acceptable \\
+4.5 and above & Excellent \\
\hline
\end{tabular}




\subsection{The lived experiences of fishermen.}

A list of lived experiences was derived from a random sample of fishermen interviewed during the period June-August 2012 in the same fishing organizations as used for the QOL survey. Three basic questions were used to prompt each respondent to yield a list of lived experiences and activities. The questions were: 1. Which activities were enjoyed in the last 2-3 weeks and activities that would like to continue in the coming weeks; 2 . Which activities were undertaken in the last 2-3 weeks which were not enjoyed, but felt some responsibility, obligation or duty to undertake; 3. Which activities that filled some of their time in the last 2-3 weeks were not included in the first two categories.

From the list of responses we prepared a four basic dimensions diagram that was used for data collection following the methodology developed by Massam et al. [24]. Four dimensions were identified, namely Mind (intellectual/thinking and reflection), Body (state of being, health), Work (activities, paid or unpaid, that require effort and some degree of commitment to be busy) and People (interactions with others) (Figure 17).

Fig. 17. Template to display data on lived experiences. From Massan et al. [24].

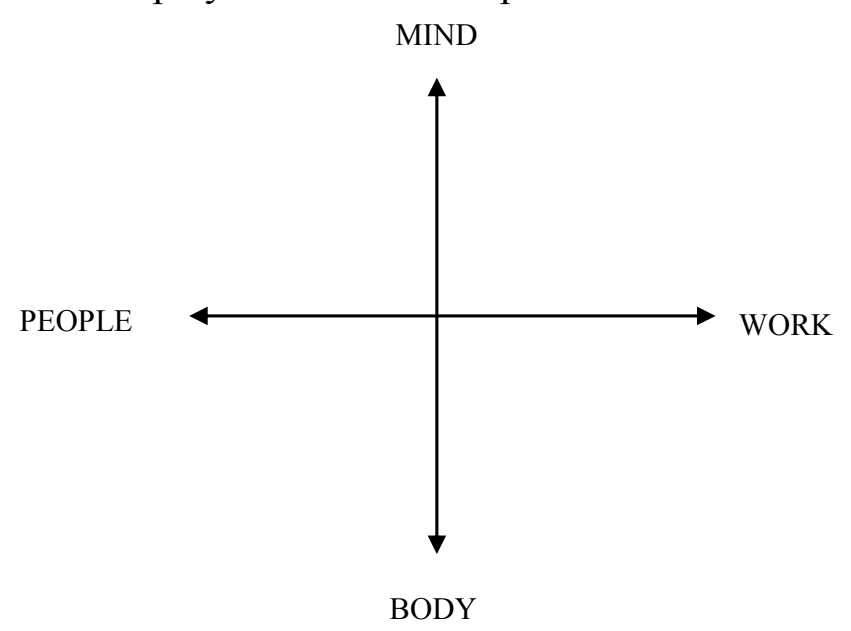

The protocol proposed by Massam et al. [24] was used to collect information from a sample of willing volunteers of 12 fishermen. A brief preamble on the concepts of lived experiences and activities was offered to each interviewee and an overview of the variety of responses derived from the long list. Then the list of activities for each of the four dimensions was presented and discussed. Each respondent was asked to identify some relevant activities that apply to their unique lived experiences, and to add others in order to identify the sets of activities for the individual for each cluster that suited their particular case and life style.

Figure 17 and the 4 clusters/dimensions of lived experiences/activities, were explained to each volunteer. For each axis the respondent was asked to reflect and think about the activities that fitted into each cluster for a specific time period namely the last 2-3 weeks. The implications of placing the mark at the center or the edge of each axis were discussed with each respondent. 
For each axis the respondent was asked to suggest a level of engagement (marked with a 0 ) with the set of activities in each cluster: ranging from low (center) to high (edge): this point was marked on each axis.

Here the respondent had to make a judgment about the selected level in terms of satisfaction: was the level to their liking or not? Was it too low or high? By how much was it too high or low? It was pointed out by the interviewer that there was neither a right nor a wrong answer to each question.

Each individual was asked to look at the gaps between the actual level of activities and the desired level for each of the four dimensions and reflected on the significance, if in the opinion of the respondent the gap should be closed, whose responsibility is it to close the gap and further, what are some of the reasons why the desired level is not actively sought. The results for all the fishermen in the survey were interpreted and summarized.

\section{Conclusions}

Quality of life of fishermen is perceived as very acceptable and excellent, family is the most important factor in their life.

An inverse moderately strong relationship between catch, marginalization and QOL score was found, while income and QOL score were directly related. In general, future and past are not better than the present.

Lived experiences analysis showed that Mind and Work dimensions are consistently important but the most unsatisfied in these communities, probably related to their poor catch perception and economic instability. Fishermen recognized their own responsibility for closing gaps but also to the government. This is an important fact in terms of sustainability to should be included in public policies. Sustainable fishing should reflect a high QOL and no gaps or very small ones in the significant dimensions elected by themselves.

Although there are social problems in the fishermen's villages along the coast of Jalisco, the assessed quality of life and lived experiences can be considered as indicators of sustainable fisheries in the region.

For future research we recommend to include the women living with fishermen in these communities to get a wider knowledge of the QOL and lived experiences of individuals.

\section{Acknowledgments}

The authors are deeply thankful to the Consejo Nacional de Ciencia y Tecnología (CONACYT), to fishermen in the fishing organizations Pescadores del Rosita, Ribera de Suchitlán, Cruz de Loreto, Ejidal La Fortuna and Puerto Viejo, and to the University of Guadalajara for providing research facilities during the investigation. 


\section{Conflict of Interest}

The authors declare no conflicts of interest.

\section{References}

1. Alcalá-Moya, G. 1995. Los pescadores del litoral del occidente de México y el turismo. Estudios Jaliscienses. 1995, 20, 27-44.

2. Bravo-Olivas, M. L. (2014). Huella ecológica de la pesca ribereña en la costa de Jalisco, México. Doctoral thesis. Universidad de Guadalajara, Puerto Vallarta, 2014; 167 p.

3. Broch, H. B. Social resilience - local responses to changes in social and natural environments. Maritime Studies, 2013 doi:10.1186/2212-9790-12-6

4. Brown, I.; Raphael, D.; Renwick, R. Quality of Life Profile, Adults, Quality of Life Resources, Adult Series. Item \#2-1, Quality of Life Research Unit, Centre for Health Promotion, University of Toronto, Toronto. 1998.

5. Chávez-Dagostino R. M.; Cifuentes-Lemus, J.L.; Andrade, E.; Bravo-Olivas, M.L.; Espinoza, R. Impacto del turismo en las comunidades pesqueras de la Bahía de Banderas, Nayarit-Jalisco. Acta Pesquera, 2009, 2, 23-40.

6. CONAPO. Consejo Nacional de Población. Población total, indicadores socioeconómicos, índice y grado de marginación y lugar que ocupa en los contextos nacional y estatal por localidad, 2010. Resource document: Secretaría de Gobernación de México (SEGOB). Available online: http://www.conapo.gob.mx/es/CONAPO/Indice_de_Marginacion_por_Localidad_2010. (accessed on 23 July 2013).

7. CONEVAL. Consejo Nacional de Evaluación de la Política de Desarrollo Social. Resource document. Available online: http://www.coneval.gob.mx/Informes/Coordinacion/Pobreza_2012/COMUNICADO_PRENSA_0 03_MEDICION_2012.pdf (accessed on 25 August 2013)

8. Cruz-Romero, M.; Espino-Barr, E.; García-Boa, A. Aspectos de la pesca ribereña en el estado de Colima. Seminario El mar y sus recursos. Aportes de la Universidad de Colima. 1991, 4, 201-208.

9. Diener, E. A value based index for measuring national quality of life. Soc. Ind. Res. 1995, 36, $107-$ 127.

10. Espino-Barr, E.; García-Boa, A.; Cabral-Solís, E.G.; Puente-Gómez, M. La pesca ribereña en la costa de Jalisco, México. In Los recursos pesqueros y acuícolas de Jalisco, Colima y Michoacán, Jiménez-Quiroz M.C.; Espino-Barr, E., Eds.; INP, SAGARPA, México D.F., 2006; pp. 514-524. 
11. Esquivel-Hernández, M.A.; Plascencia-Reyes, E.C. Análisis de la problemática de la pesca costera de los estados de Jalisco y Colima, México. Biology Thesis, University of Guadalajara, Guadalajara, 1999; 240 p.

12. Evans, D.R. Enhancing quality of life in the population at large, Soc. Ind. Res. 1994, 33, 47-88.

13. FAO. Indicators for sustainable development of marine capture fisheries. FAO Technical Guidelines for Responsible Fisheries, No. 8: Rome, 1999; 68 p.

14. García-Rivera, L. M. Caracterización ictiológica de Bahía de Banderas Jalisco-Nayarit, México. Marine Biology Thesis, Instituto Tecnológico de Bahía de Banderas, La Cruz de Huanacaxtle, 2006; $246 \mathrm{p}$.

15. Hagerty, M. R. Unifying livability and comparison theory: cross-national time-series analysis of life-satisfaction. Soc. Ind. Res. 1999, 47, 343-356.

16. Jeffres, L.W.; Dobos, J. Separating people's satisfaction with life and public perceptions of the quality of life in the environment. Soc. Ind. Res, 1995, 34, 181-211.

17. Helliwell, J.; Layard, R.; Sachs, J. World Happiness Report.Columbia Univerity; Earth Institute, New York, 2012, 167 p.

18. Kahneman, D. Thinking, Fast and Slow. New York: Farrar, Strauss and Giroux. New York, 2011; 499p.

19. Kenny, C. Why Are We Worried About Income? Nearly Everything that Matters is Converging. World Development, 2005, 33, 1-19.

20. Lucano-Ramírez, G.; Ruiz-Ramírez, S.; Aguilar-Palomino, B.; Rojo-Vázquez, J. A. Listado de las especies de peces de la región costera de Jalisco y Colima, México. Ciencia y Mar, 2001, 5, 13-20.

21. Magee, L. Scerri, A.; James, P. Measuring Social Sustainability: A Community-Centred Approach. Applied Research Quality Life, 2012, 7, 239-261.

22. Massam. B. Quality of Life: public planning and private living. Progress in Planning, 2002, 58, 142-229.

23. Massam, B.; Hracs, B.; Espinoza, R. Lived Experiences. University of Toronto. Toronto, 2012, 50 p.

24. Massam, B.; Everitt, J. What the People Say: A Study of Quality of Life in Three Towns in Jalisco, Mexico. Can. J. Urban Res., 2001, 10, 293-316.

25. Massam, B.; Everitt, J.; Andrade-Romo, E.; Chávez-Dagostino, R.M.; Cortés-Lara, M.; CupulMagaña, A. et al. Quality of life in the Puerto Vallarta region of Jalisco state, Mexico. Brandon University, Brandon, 2003, $44 \mathrm{p}$.

26. Moncayo-Estrada, R.; Castro-Aguirre, J. L.; de La Cruz- Agüero, J. Lista sistemática de la ictiofauna de Bahía de Banderas, México. Rev.Mex. de Biodiv., 2006, 77, 67-80. 
27. Pérez-Peña, M. Subsistema productivo. Subsistema de pesca. Proyecto de Ordenamiento Ecológico Territorial del Estado de Jalisco.Gobierno del Estado de Jalisco. Available online: http://siga.jalisco.gob.mx/moet/ (accessed on 20 June 2014).

28. Pollnac, R. B.; Poggie, J. J. The structure of job satisfaction among New England fishermen and its application to fisheries management policy. Am. Anthropol., 1998, 90, 888-901.

29. Pollnac, R. B.; Poggie, J: J. Happiness, Well-being and Psychocultural Adaptation to the Stresses Associated with Marine Fishing. Hum. Ecol. Rev., 2008, 15, 194-200.

30. Ramírez-Acosta, M. Calidad de vida relacionada con salud y redes sociales de los pescadores del Corregimiento La Playa. Proyect to obtain the Master Degree in Social Development, Fundación Universidad del Norte, Barranquilla Colombia. Resource document: Universidad del Norte, Karl C. Parrish library. Available online: http://manglar.uninorte.edu.co/bitstream/handle/10584/678/1_HITOS\%20DE\%20LA\%20PERSPE CTIVA\%20MOLAR_PSICOLOGIA\%20DESDE\%20EL\%20CARIBE_NO\%2012.pdf?sequence= 1 (accessed on 3 October 2013).

31. Renwick, R.; Brown, I. The center for health promotion's conceptual approach to quality of life: being, belonging and becoming. In: Quality of Life Health Promotion and Rehabilitation, Renwick, R.; Brown, I.; Nagler, M., Eds.; Sage Publications, Thousand Oaks, 1996; pp. 75-88.

32. Ríos-Jara, E.; Pérez-Peña, M.; Juárez-Carrillo, E.; López-Uriarte, E. Recursos pesqueros de la costa de Jalisco. Guadalajara, Jalisco, Mexico: Universidad de Guadalajara. Guadalajara, 2001, $159 \mathrm{p}$.

33. Robinson, T. Cooperation and quality of life among Bering Sea fishermen and their families. Doctoral Thesis. The University of Edinburgh. Edinburgh. 2007, 280 p.

34. Rojo-Vázquez, J.A.; Aguilar-Palomino, B.; Galván-Piña, V. H.; Godínez-Domínguez, E.; Hernández-Vázquez, S.; Ruiz-Ramírez, S.; Lucano-Ramírez, G. Ictiofauna de la pesquería ribereña en Bahía Navidad, Jalisco, México asociada al evento El Niño1997-1998. Rev. Biol. Trop., 2001, 49, 841-854.

35. Udho, A. J. Assessment of Quality of Life of the Fishing Settlements in Ibaka and James Town Communities in Nigeria. Indian Res. J. Ext. Edu., 2008, 8 (1), 76-78.

36. Veenhoven, R. Developments in satisfaction-research. Soc. Ind. Res., 1996, 31, 1-46.

37. Villaseñor-Anguiano, S.; García de Quevedo, R. La Universidad de Guadalajara y la pesca en Jalisco. Research Report Universidad de Guadalajara, Guadalajara, 1990, 74 p.

38. World Bank. Poverty Overview. Resource document: Indicators. Available online: http://www.worldbank.org/en/topic/poverty/overview (accessed on 15 October 2013). 
39. WWF.

Sustainable

fishing.

Available

online:

http://wwf.panda.org/what_we_do/how_we_work/conservation/marine/sustainable fishing/ (accesed on 28 September 2014).

(C) 2014 by the authors; licensee MDPI, Basel, Switzerland. This article is an open access article distributed under the terms and conditions of the Creative Commons Attribution license. 